\title{
Entansif hindi yetiştiriciliği işletmelerinde kârlılık ve verimlilik analizleri **
}

\author{
Cevat SIPAHi ${ }^{1, a^{*}}$, Yavuz, CEVGER ${ }^{2, b}$ \\ ${ }^{1}$ Mehmet Akif Ersoy Üniversitesi Veteriner Fakültesi, Hayvan Sağll̆ğ Ekonomisi ve İşletmeciliği Anabilim Dalı, 15030, Merkez, Burdur, Türkiye \\ ${ }^{2}$ Ankara Üniversitesi Veteriner Fakültesi, Hayvan Să̆lığı Ekonomisi ve Isşletmeciliği Anabilim Dall, 06110, Dıșkapı, Ankara, Türkiye \\ ORCID: 0000-0002-4434-1419 ${ }^{a}$;0000-0002-2806-2532 ${ }^{b}$
}

\begin{abstract}
MAKALE BILGISI/ ÖZ O O
ARTICLE

INFORMATION:

Geliş / Received:

10 Aralık 2020

10 December 2020

Revizyon / Revised:

5 Ocak 2021

5 January 2021

Kabul / Accepted:

5 Mart 2021

5 March 2021

Bu araştırma, entegre firmalara bağlı olarak sözleşmeli hindi yetiştiriciliği yapan işletmelerin ekonomik analizini yaparak, işletmelerde kârlılık ve verimliliği etkileyen, iktisadi faktörlerin dağılımlarını tespit etmek amacıyla yapılmıştır. Araştırmanın materyalini, Bolu, Eskişehir, İzmir, İzmit ve Manisa illerinde bulunan entansif hindi yetiştiriciliği işletmelerinden tabakalı örnekleme yöntemiyle seçilen 65 adet işletmeden anket yoluyla sağlanan 2006 - 2007 yıllarına ait veriler oluşturmuştur. Elde edilen verilerin değerlendirilmesinde, verimlilik analizleri için, Basamaklı (Stepwise) Regresyon Analizi prosedüründen, kârlılık analizleri için de rantabilite rasyolarından yararlanılmıştır. Hindi endüstrisinde işletmeler genelinde ortalama kesim yaşı 2006 y1lında 119,9 gün, 2007 yılında 111,9 gün, ortalama ölüm oranı 2006 yılında \%8,8; 2007 yılında \%7,3; ortalama CA 2006 yılında 10,8 kg, 2007 yılında 9,5 kg, FCR 2006 y1lında 2,557; 2007 yılında 2,472; AVF 2006 yılında 368,18; 2007 yılında 361,75 olarak bulunmuştur. Araştırmada kullanılan girdi unsurlarının toplam girdi içerisindeki oranları incelendiğinde yem masraflarının 2006 yılında $\% 75,5 ; 2007$ yılında $\% 73$ oranında, civciv/palaz masrafinın 2006 yılında \%10,6; 2007 yılında \%12,7; toplam amortisman masraflarının 2006 ve 2007 yılında \%4,1; genel idare giderlerinin 2006 ve 2007 yılında \%2,7; bakım - onarım masraflarının 2006 yılında ve 2007 yılında \%2,2; 1sıtma - aydınlatma masraflarının 2006 ve 2007 yılında \%2 oranında olduğu tespit edilmiştir. Diğer masraf unsurlarının toplam maliyetler içindeki payının 2006 yılında \%2,9; 2007 yılında $\% 4,1$ olduğu hesaplanmıştır. İşletmeler genelinde O/I oranının 2006 yılında ortalama 1,2; 2007 yılında ortalama \%1,22 olduğu belirlenmiştir. Mali rantabilite rasyosu işletmeler genelinde 2006 yılında ortalama 0,$127 ; 2007$ y1lında ortalama 0,132 olarak; rantabilite faktörü değeri 2006 yılında ortalama 0,165; 2007 yılında ortalama 0,175 olarak hesaplanmıştır.

Anahtar Sözcükler:

Hindi

Kârll11k

Analysis of profitability and productivity of intensive turkey breeding enterprises

Sözleşmeli yetiştiricilik

Verimlilik analizi

Keywords:

Contract growing

Productivity

Profitability analysis

Turkey

ABSTRACT:

This research was carried out in order to determine the distribution of economic factors affecting profitability and productivity in enterprises by conducting an economic analysis of the contracted turkey farming enterprises under integrated companies. The material of the study consisted of data from the years 2006 - 2007 obtained from 65 enterprises selected by the stratified random sampling method from the intensive turkey farming enterprises in the provinces of Bolu, Eskişehir, İzmir, İzmit and Manisa. In the evaluation of the data obtained, the Stepwise Regression Analysis procedure was used for productivity analysis and the profitability ratios were used for profitability analysis. Average slaughter age across enterprises in the turkey industry was 119.9 days in 2006, 111.9 days in 2007, the average mortality rate was $8.8 \%$ in 2006; $7.3 \%$ in 2007; average live weight was $10.8 \mathrm{~kg}$ in 2006, $9.5 \mathrm{~kg}$ in 2007, and FCR 2,557 in 2006; 2,472 in 2007; European efficiency factor was 368.18 in 2006 and 361.75 in 2007 . When the rate of inputs used in the study were examined, feed costs rate were identified to be $75.5 \%$ in $2006 ; 73 \%$ in 2007 , chick/poult costs rate were identified to be $10.6 \%$ in $2006 ; 12.7 \%$ in 2007 , total depreciation charge rate were identified to be $4.1 \%$ both in 2006 and 2007 , general administration expenses rate were identified to be $2.7 \%$ both in 2006 and 2007 , maintenance - repair costs rate were identified to be $2.2 \%$ both in 2006 and 2007 , heating - lighting costs were identified to be $2 \%$ both in 2006 and 2007 . Other costs rate were calculated as $2.9 \%$ in 2006 and $4.1 \%$ in 2007. The enterprises' output/input ratios were determined as 1.2 in 2006 and 1.22 in 2007. The enterprises' financial profitability ratios were calculated as 0.127 in 2006 and 0.132 in 2007. Profitability factor values of the enterprises were identified as 0.165 in 2006 and 0.175 in 2007.
\end{abstract}

How to cite this article: Sipahi C, Cevger Y: Entansif hindi yetiştiriciliği işletmelerinde kârlılık ve verimlilik analizleri. Veteriner Hekimler Dernegi Dergisi, 92(2): 96-110, 2021, DOI: $10.33188 /$ vetheder. 838670

* Sorumlu Yazar e-posta adresi / Corresponding Author e-mail address: cevatsipahi@gmail.com

**Bu makale ilk yazarın, ikinci yazar danışmanlığında yaptığı aynı başlıklı Doktora Tezi’nden özetlenmişstir. 


\section{Giriș}

Kanatlı sektörü, hayvancılık sektörünün diğer alt sektörlerine göre prodüktif üretim yapısı sayesinde, hem dünyada hem de Türkiye' de hayvansal protein açığının kapatılmasında büyük bir önem taşımaktadır. Örneğin ABD'de 1950'lerden itibaren, üretim ve pazarlama sürecinde yaşanan verimlilik artışlarının kanatlı eti reel fiyatlarında kırmızı ete oranla daha büyük bir düşüş yaşanmasını sağlamasıyla toplumun et tüketim tercihi kırmızı etten beyaz ete yönelim göstermiştir (10). Sektör Türkiye'de de özellikle gelişmeye başladığı 1990'lı y1llardan itibaren rakiplerine göre daha uygun fiyatlarla ürün sunması, ürün kalite ve çeşitliğini sürekli artırması sayesinde günümüzde üretim, tüketim ve talep bakımından et sektöründe hâkim konuma gelmiştir.

Kanatlı sektörüne önderlik eden etlik piliç üretiminin başarısı, dünyada ticari olarak üreticiliği yapılan kanatlılar arasında ikinci sırada bulunan hindi yetiştiriciliğinin de önünü açmıştır. Kanatlı sektörünün bir üretim kolu olan hindi yetiştiriciliğinde; genetik, üretim ve işleme konusunda kazanılan teknik uzmanlık, hayvan türlerinin pek çoğuna kıyasla, bir kg hindi etinin daha az yem ve daha az zaman harcanarak üretilmesini sağlamıştır.

Kuzey Amerika ülkeleri, Avrupa ve İsrail tarafından çok iyi bilinen ve tüketilen hindi etinin özellikle Türkiye ve diğer gelişmekte olan ülkeler tarafindan kanatlı sektöründe sahip olduğu potansiyel göz ardı edilmektedir. Türkiye'de kanatlı sektörü, günümüze kadar tek başına etlik piliç üretimine ağırlık vermiş, hindi yetiştiriciliği, etlik piliç üretimiyle rekabet edemeyeceği için yok olmaya mahkûm bir sektör gibi algılanarak gelişimi teşvik edilmemiştir. Oysa hindi yetiştiriciliği piliç eti üretiminin rakibi olmaktan ziyade onu tamamlayıcı bir sektördür. Kanatlı sektörüne hindi yetiştiriciliğinin dâhil edilmesinin, ürün çeşitliliğini artıracağı, piliç etine göre farklı bir lezzet alternatifi sunulmasını sağlayacağı, günümüzde hindi etinin, sağlıklı beslenme trendinin vazgeçilmez bir parçası olması sebebiyle kendisine özgü bir tüketici kitlesi oluşturacağı dolayısıyla genel olarak kanatlı eti tüketimini artıracağı düşünülmektedir (6).

$\mathrm{Bu}$ çerçevede bu çalışmanın amacı, entegre firmalara bağlı olarak hindi yetiştiriciliği yapan işletmelerin ekonomik analizini yaparak; işletmelerde kârlılık ve verimliliği etkileyen, iktisadi faktörlerin dağılımlarını tespit etmek ve hindi yetiştiriciliğinde optimum kaynak kullanımı yanında, kârlılık ve verimliliği yükseltmek için alınabilecek önlemleri saptamaktır.

\section{Gereç ve Yöntem}

$\mathrm{Bu}$ araştırmanın gerecini, Bolu, Eskişehir, İzmir, İzmit ve Manisa illerinde bulunan entansif hindi yetiştiriciliği işletmelerinden tabakalı rastgele örnekleme yöntemiyle belirlenmiş bir yetiştirici grubuna ait 2006 - 2007 yılları arası üretim verileri oluşturmaktadır. Veriler her üretim döneminin sonunda yetiştiricilerle yüz yüze anket yapılarak elde edilmiştir.

Araştırma kapsamına alınacak işletmelerin belirlenebilmesi amacıyla Bolu, Eskişehir, İzmir, İzmit ve Manisa illerinde bulunan ve 2006 yllında Türkiye'deki mevcut hindi eti üretimin yaklaşık \%81'ini sağlayan (1) 5 hindi entegrasyonun yetkilileriyle BESD-BİR aracılığıyla iletişim kurulup bir envanter çalışması yapılmış ve 2006 yılında bu 5 entegrasyona bağlı olarak sözleşmeli çalışan entansif hindi yetiştiriciliği işletmesi sayısının 500 civarında olduğu tespit edilmiştir. İşletmelerin ölçeklendirilmesinde erkek ve dişi hindiler arasındaki kümese konulma oranı ve boyut bakımından önemli farklar olduğu için çalışma sonuçlarını yanlış yönlendirebileceği düşünülerek hindi sayısı kriter olarak kullanılmamıştır. Bunun yerine işletmenin $\mathrm{m}^{2}$ cinsinden kapalı alanı kullanılmıştır. İşletmelerden yetiştiricilikte kullanılabilir alanı $0-700 \mathrm{~m}^{2}$ arasında yer alanlar küçük ölçekli, $701-1200 \mathrm{~m}^{2}$ arasında yer alanlar orta ölçekli ve $1201 \mathrm{~m}^{2}$ ve üzeri alana sahip olanlar büyük ölçekli işletmeler olarak sınıflandırılmışlardır. Örneklem hacmini belirleyebilmek için ölçeklere göre üçer adet olmak üzere 9 işletmede, bir işletme dönemini kapsayacak biçimde ön örneklem çalışması yapılmıştır. Ön örneklem sonucunda kâr bakımından varyans değerinin; küçük ölçekli işletmelerde 13.605 TL (9.461 \$), orta ölçekli işletmelerde 19.411 TL (13.498,5 \$), büyük ölçekli işletmelerde 55.022 TL (38.262,6 \$) olduğu saptanmıştır. Bunun üzerine örneklem hacmini belirlemek için bilinen bir evren ve belirli varyansa göre örneklem hacmini belirlemede kullanılan, 


$$
n=\frac{N z_{\alpha}^{2} \sigma^{2}}{d^{2}(N-1)+z_{\alpha}^{2} \sigma^{2}}
$$

formülünden yararlanılmıştır (7). Örneklemden elde edilecek tahminlerin küçük ölçekli işletmelerde 6.000 TL (4.172,4 \$), orta ölçekli işletmelerde 9.000 TL $(6.258,7$ \$) ve büyük ölçekli işletmelerde 25.000 TL (17.385,1 \$) arasında bulunması durumunda en küçük örneklem genişliği, küçük ölçekli işletmeler için 19, orta ölçekli işletmeler için 17 ve büyük ölçekli işletmeler için 18 adet olarak hesaplanmıştır. Böylece çalışmada işletme ölçeğine göre tabakalı rastgele örnekleme metoduyla 500 işletme içinde 54 adet işletmenin örneklem hacmi için yeterli olacağ 1 görülmüştür. Ancak tedbir amaçlı olarak her grup için yeterli görülen örneklem hacmine 5 işletme daha ilave edilerek toplam 69 işletme entegrasyon yetkilileriyle yapılan ön görüşmeler ile belirlenerek araştırma kapsamına dâhil edilmiştir. Ancak araştırma kapsamına alınan işletmelerden 4 adeti, 2006 - 2007 yılları arasında hindi eti üretimini tamamen bıraktığ için çalışma dışında kalmıştır. Sonuç olarak çalışma, 22 (\%33,8)'şer adeti küçük ve büyük ölçekli, 21 (\%32,3) adeti orta ölçekli olmak üzere 65 adet işletmeden elde edilen verilerle tamamlanabilmiştir. Entegrasyon yetkilileriyle yapılan görüşmeler sonucunda aynı dönemde araştırma kapsamındaki 5 entegrasyona bağlı sözleşmeli yetiştirici sayısının da yaklaşı \% 25 azalarak 400' e düştüğü öğrenilmiştir. Bu bakımdan araştırma sonunda işletme sayısındaki azalmaya karşın, örneklemin evreni temsil gücü 2006 yılında yapılan planlamanın üzerine çıkmıştır. 2007 yılında çalışmanın evreni temsil etme gücünü artıran başka gelişmeler de olmuştur. Küçük ölçekli firmaların bir bölümünün piyasadan çekilmesiyle, 2007 yılı itibariyle araştırma kapsamındaki entegrasyonların, hindi eti üretimindeki hâkimiyetinin 2006 yılına göre \%9 artarak Türkiye hindi eti üretiminin yaklaşık \%90'ına ulaştı̆̆ (2) belirlenmiştir.

İşletmelere uygulanan anketlerden elde edilen verilerin bilgisayar ortamında değerlendirilmesinde ve yapılan hesaplamalarda, Microsoft Excel (13) ve SPSS for Windows 12.0 (12) programlarından yararlanılmıştır. Bu amaçla işletme sonuçlarının ve kasaplık hindi üretim maliyetlerinin hesaplanabilmesi için maliyeti oluşturan masraf unsurlarını, toplam geliri, tali gelirleri, birim kasaplık hindi üretim maliyeti ve net kâr/zarar miktarını gösteren bir ekonomik analiz tablosu hazırlanmıştır.

Regresyon analizlerinde, hindi eti üretiminde 2006 - 2007 yılları arasında işletme faaliyetleri, kâr fonksiyonu çerçevesinde incelenmiştir.

Araştırma kapsamına alınan işletmelerde "kg canlı ağırlık (CA) başına sağlanan işletme kârına" etkili faktörlerin kantitatif olarak hesaplanabilmesi için öncelikle anket yoluyla sağlanan veriler Microsoft Excel (13) programına aktarılarak kg CA başına kâr ve yine kg CA başına masraf unsurları hesaplanmıştır.

Teknik ve kısmi teknik değerlendirme rasyoları aşağıdaki şekilde hesaplanmıştır (15).

$$
\begin{aligned}
& \text { Yemden Yararlanma Oranı }(\mathrm{FCR})=\frac{\text { Tüketilen toplam yem miktarı }(\mathrm{kg})}{} \\
& \text { Toplam CA (kg) } \\
& \text { Ölüm Oranı (ÖO) } \\
& \text { Toplam ölen hindi sayısı (adet) x } 100 \\
& \text { Dönem başı toplam hindi sayısı (adet) } \\
& \text { Avrupa Verimlilik Faktörü }(\mathrm{AVF})=\frac{\text { Ortalama CA }(\mathrm{g}) \mathrm{x} \text { Yaşama oranı }(\%)}{\text { FCR x Kesim Yaşı } \mathrm{x} 10} \\
& \text { Kısmi Teknik Verimlilik Yem }=\quad \text { Dönem sonu toplam hindi ağırlığı }(\mathrm{kg}) \\
& \text { Kuru madde cinsinden toplam yem }(\mathrm{kg}) \\
& \text { Kısmi Teknik Verimlilik İşgücü } \\
& =\frac{\text { Dönem sonu toplam hindi ağırlı̆̆ } 1(\mathrm{~kg})}{\text { Kullanılan işgücü (gün) }}
\end{aligned}
$$

Kg CA başına kâr (Y) ile kâra etkisi olduğu düşünülen değişkenlerin arasındaki ilişkinin yönünü ve niceliğini tahmin etmek amacıyla çoklu regresyon analiz metodu kullanılmıştır. Çoklu regresyon analizi, basit regresyon analizinden farklı olarak; bağımsız değişkenlerin her birinin, bağımlı değişkendeki toplam varyasyonu açılamasından yola çıkılarak yapılmaktadır (11). Oluşturulan olası regresyon denklemi aşağıda gösterilmiştir.

$\mathrm{Y}=\mathrm{f}\left(\mathrm{X}_{1}, \mathrm{X}_{2}, \mathrm{X}_{3}, \mathrm{X}_{4}, \mathrm{X}_{5}, \mathrm{X}_{6}, \mathrm{X}_{7}, \mathrm{X}_{8}\right)$

Bu bağıntıyı aynı zamanda, 
$Y=\beta_{0}+\beta_{1} X_{1}+\beta_{2} X_{2}+\beta_{3} X_{3}+\beta_{4} X_{4}+\beta_{5} X_{5}+\beta_{6} X_{6}+\beta_{7} X_{7}+\beta_{8} X_{8}$ $+\beta_{\mathrm{n}} \mathrm{X}_{\mathrm{n}}$ şeklinde ifade etmek mümkündür. Burada $\beta_{0}$ sabit (constant) katsayısı, $\beta_{1}, \beta_{2}, \beta_{3} \ldots \beta_{8}$ regresyon katsayılarıdır. $\beta_{\mathrm{i}}(\mathrm{i}=1,2,3,4,5,6,7,8)$ katsayılarının her biri, önünde bulunduğu bağımsız değişkenlerin Y'nin değişimi üzerine etkilerini belirtmektedir (5).

Y: Kâr (TL/kg CA)

$\mathbf{X}_{\mathbf{1}}$ : Canlı Hindi Satış Fiyatı (TL/kg CA)

$\mathbf{X}_{2}$ : Civciv/Palaz Maliyeti (TL/kg CA)

$\mathbf{X}_{3}$ : Isıtma - Aydınlatma Masrafları (TL/kg CA)

$\mathbf{X}_{4}$ : İşçilik Maliyeti (TL/kg CA)

$\mathbf{X}_{\mathbf{5}}$ : Kuru Madde Cinsinden Kesif Yem Masrafı (TL/kg CA)

$\mathbf{X}_{\mathbf{6}}$ : Toplam Diğer Masraflar (bakım ve onarım+amortismanlar+genel idare+diğer) (TL/kg CA)

$\mathbf{X}_{7}$ : Veteriner Hekim, Sağlık, Dezenfeksiyon ve Temizlik Masrafları (TL/kg CA)

$\mathbf{X}_{\mathbf{8}}$ : Yemden Yararlanma Oranı (FCR)

değerlerini ifade etmektedir.

\section{Bulgular}

\section{İşletmelerde yetiştirici özelliklerine ilişkin genel bulgular ve değerlendirilmesi:}

İşletmelerde çalışan işgücünün yaş grupları itibariyle dağılımı Tablo 1'de sunulmuştur.

Tablo 1: İşletmelerde çalışan işgücünün yaş grupları itibariyle dağılımı

Table 1: Distribution of the workforce employed in enterprises by age groups

\begin{tabular}{|c|c|c|c|c|c|c|c|c|c|c|c|c|c|c|}
\hline & \multicolumn{4}{|c|}{ İşletme Sahibi (n) } & \multicolumn{4}{|c|}{ Aile İşgücü (n) } & \multicolumn{2}{|c|}{ Yabancı İşgücü (n) } & \multicolumn{4}{|c|}{ Toplam İşgücü (n) } \\
\hline Yaş & Erkek & Kadın & Toplam & $\%$ & Erkek & Kadın & Toplam & $\%$ & Erkek & $\%$ & Erkek & Kadın & Toplam & $\%$ \\
\hline $0-20$ & 0 & 0 & 0 & 0,0 & 9 & 7 & 16 & 23,2 & 0 & 0,0 & 9 & 7 & 16 & 10,9 \\
\hline $31-40$ & 15 & 2 & 17 & 26,2 & 13 & 12 & 25 & 36,2 & 3 & 23,1 & 31 & 14 & 45 & 30,6 \\
\hline $41-50$ & 21 & 3 & 24 & 36,9 & 10 & 8 & 18 & 26,1 & 3 & 23,1 & 34 & 11 & 45 & 30,6 \\
\hline 61 ve üstü & 2 & 0 & 2 & 3,1 & 0 & 1 & 1 & 1,4 & 0 & 0,0 & 2 & 1 & 3 & 2,0 \\
\hline TOPLAM & 59 & 6 & 65 & 100 & 37 & 32 & 69 & 100 & 13 & 100 & 109 & 38 & 147 & 100 \\
\hline TOPLAM \% & 40,1 & 4,1 & 44,2 & - & 25,2 & 21,8 & 47,0 & - & 8,8 & - & 74,1 & 25,9 & 100 & - \\
\hline
\end{tabular}

İşletmelerde çalışan işgücünün yaş grupları itibariyle dağılımı incelendiğinde kadın işletme sahibi oranının \%10 civarında olduğu tespit edilmiştir. Çalışmada yabancı işgünün \%100'ünün erkek olduğu dikkate değer diğer bir olgudur. Hindi yetiştiriciliğinde işgücü kaynağı olarak yabancı işgücü kullanım oranı Ayala ve ark. (4) çalışmasıyla benzer nitelik taşımaktadır.

Araştırma kapsamına alınan işletme sahiplerinin eğitim durumları ve yaşlarına ilişsin bulgular Tablo 2'de verilmiştir. 
Tablo 2: İşletme sahiplerinin eğitim durumları ve yaşlarına ilişkin bulgular

Table 2: Findings regarding the educational background and age of business owners

\begin{tabular}{lcclcc}
\hline Eğitim Durumu & $\mathbf{n}$ & $\mathbf{\%}$ & Yaş Durumu & $\mathbf{n}$ & $\mathbf{\%}$ \\
Okur-Yazar Değil & 1 & 1,5 & $21-30$ & 11 & 16,9 \\
İlkokul & 30 & 46,2 & $31-40$ & 17 & 26,2 \\
Ortaokul & 14 & 21,5 & $41-50$ & 24 & 36,9 \\
Lise & 16 & 24,6 & $51-60$ & 11 & 16,9 \\
Üniversite & 4 & 6,2 & 61 ve üstü & 2 & 3,1 \\
Toplam & 65 & 100,0 & Toplam & 65 & 100,0 \\
\hline
\end{tabular}

Araştırmada işletme sahiplerinin eğitim durumları; Nijerya'da yürütülen çalışmadaki (4) hindi yetiştiricilerinin eğitim düzeyinin altında bulunmuştur. Bu durum Türkiye'de hindi yetiştiricilerinin eğitim düzeyinin oldukça düşük olduğunu, Afrika ülkelerindeki yetiştiricilerin eğitim düzeyinin bile altında olduğunu göstermektedir.

İşletme ölçekleri itibariyle işletme sahiplerinin; yetiştiriciliğe başlama biçimleri, tek gelir kaynağı hindi yetiştiriciliği olanların oranları ve hindi yetiştiriciliği dışında ek kaynakları sırasıyla Tablo 3, Tablo 4 ve Tablo 5'de verilmiştir.

Tablo 3: İşletme ölçekleri itibariyle yetiştiriciliğe başlanma biçimi

Table 3: The way of starting breeding in terms of business scales

\begin{tabular}{|c|c|c|c|c|c|c|c|c|}
\hline & \multicolumn{2}{|c|}{ Küçük } & \multicolumn{2}{|r|}{ Orta } & \multicolumn{2}{|c|}{ Büyük } & \multicolumn{2}{|c|}{ İşletmeler Geneli } \\
\hline & $\mathbf{n}$ & $\%$ & $\mathbf{n}$ & $\%$ & $\mathbf{n}$ & $\%$ & $\mathbf{n}$ & $\%$ \\
\hline Komşu teşviki ile & 2 & 9,1 & 2 & 9,5 & - & - & 4 & 6,2 \\
\hline Geçim kaynă̆ 1 olarak & 14 & 63,6 & 12 & 57,1 & 12 & 54,5 & 38 & 58,5 \\
\hline Ek iş amaciyla & 6 & 27,3 & 6 & 28,6 & 7 & 31,8 & 19 & 29,2 \\
\hline Hobi olarak & - & - & 1 & 4,8 & 3 & 13,6 & 4 & 6,2 \\
\hline
\end{tabular}

Tablo 4: İşletme ölçekleri itibariyle tek gelir kaynağı hindi yetiştiriciliği olan işletmeci sayısı ve oranları

Table 4: The number and rate of business operators whose only source of income is turkey breeding by business scales

\begin{tabular}{ccccccccc}
\hline & \multicolumn{2}{c}{ Küçük } & \multicolumn{2}{c}{ Orta } & \multicolumn{2}{c}{ Büyük } & \multicolumn{2}{c}{ Isşletmeler Geneli } \\
$\mathbf{n}$ & $\mathbf{\%}$ & $\mathbf{n}$ & $\mathbf{\%}$ & $\mathbf{n}$ & $\mathbf{\%}$ & $\mathbf{n}$ & $\mathbf{\%}$ \\
\hline 3 & 13,6 & 6 & 28,6 & 5 & 22,7 & 14 & 21,5 \\
\hline
\end{tabular}


Tablo 5: İşletme ölçekleri itibariyle ek gelir kaynağı olan işletmecilerin, hindi yetiştiriciliği dışında ek gelir kaynakları

Table 5: Additional income sources for the operators other than turkey breeding in terms of business scales

\begin{tabular}{lcccccccccc}
\hline & \multicolumn{2}{c}{ Çiftçilik } & \multicolumn{2}{c}{ Emekli Maaşı } & \multicolumn{2}{c}{ Hayvancılık } & \multicolumn{2}{c}{ Nakliyat } & \multicolumn{2}{c}{ Diğer } \\
& $\mathbf{n}$ & $\mathbf{\%}$ & $\mathbf{n}$ & $\mathbf{\%}$ & $\mathbf{n}$ & $\mathbf{\%}$ & $\mathbf{n}$ & $\mathbf{\%}$ & $\mathbf{n}$ & $\mathbf{\%}$ \\
\hline Küçük & 12 & 63,2 & 3 & 15,8 & 1 & 5,3 & 3 & 15,8 & 0 & 0,0 \\
Orta & 6 & 40,0 & 2 & 13,3 & 1 & 6,7 & 1 & 6,7 & 5 & 33,3 \\
Büyük & 5 & 29,4 & 2 & 11,8 & 4 & 23,5 & 1 & 5,9 & 5 & 29,4 \\
İşletmeler Geneli & 23 & 45,1 & 7 & 13,7 & 6 & 11,8 & 5 & 9,8 & 10 & 19,6 \\
\hline
\end{tabular}

Entansif hindi yetiştiriciliği işletmelerinde üretim faaliyetine genel olarak bakıldığında ihtisaslaşmanın yeterince sağlanamadığı görülmektedir. İhtisaslaşmış yetiştirici oranı \%21,5 (14 işletme) olup geri kalan işletmelerde hindi yetiştiriciliği dışında, çiftçilik, hayvancılık, nakliyat, ticaret gibi üretim faaliyetlerinin de yapıldığı görülmektedir. Hindi yetiştiriciliği dışında ek geliri bulunan işletme oranı, üretimin \%90'ını gerçekleştiren 5 entegrasyona bağlı yetiştiricilerin kullanıldığ bu çalışmada \%78,5 (51 işletme); Yalçın ve ark. (17) tarafından 2008 yılında 4 hindi entegrasyonunda gerçekleştirilen çalışmada benzer biçimde \%82 olarak tespit edilmiştir.

Yapılan görüşmeler ve araştırma sırasında edilen deneyimler hindi yetiştiricilerinin, hindi yetiştiriciliğini etlik piliç yetiştiriciliğine tercih etmelerinde önde gelen sebebin; ilk 6 haftalık devrenin ardından, 6 - 20 haftalık dönemde hindi yetiştiriciliğinin, piliç yetiştiriciliğine göre daha az emek ve daha az bakım gerektirmesi olduğunu göstermiştir. $\mathrm{Bu}$ sebeple ek bir iş daha yapmak isteyen yetiştirici için hindi yetiştiriciliği daha cazip hale gelmektedir. İşletmelerin \%29,2'sinin hindi yetiştiriciliğini ek gelir kaynağı olarak gördüklerini beyan etmeleri de bu görüşü desteklemektedir. Etlik piliç sektörü, yetiştiricilik bakımından daha çok uzmanlık gerektirdiği gibi aynı zamanda daha emek yoğun bir sektördür. Nitekim Yalçın ve ark. (17) çalışmalarında etlik piliç sektöründe ihtisaslaşmanın \%36'nın üzerinde olduğu görülmüştür.

\section{İşletmelere ilişkin genel bulgular ve değerlendirilmesi:}

Araştırma sonucunda 65 işletmenin kümes varlığının toplam 83 adet olduğu tespit edilmiştir. İşletmelerin sahip olduğu kümeslerin işletme ölçekleri itibariyle kuruluş yılları ve finansman kaynakları sırasıyla Tablo 6'da verilmiştir.

Tablo 6: İşletme ölçekleri itibariyle işletmelerin kuruluş yılları

Table 6: Establishment years of businesses in terms of business scales

\begin{tabular}{|c|c|c|c|c|c|c|c|c|}
\hline \multirow[t]{2}{*}{ İşletme Ölçeği } & \multicolumn{2}{|c|}{1985 ve öncesi } & \multicolumn{2}{|c|}{$1986-1995$ arası } & \multicolumn{2}{|c|}{ 1996-2005 arası } & \multicolumn{2}{|r|}{2006} \\
\hline & $\mathrm{n}$ & $\%$ & $\mathbf{n}$ & $\%$ & $\mathbf{n}$ & $\%$ & $\mathbf{n}$ & $\%$ \\
\hline Küçük & 3 & 13,6 & 4 & 18,2 & 15 & 68,2 & 0 & 0,0 \\
\hline Orta & 1 & 4,3 & 2 & 8,7 & 16 & 69,6 & 4 & 17,4 \\
\hline Büyük & 0 & 0,0 & 4 & 10,5 & 34 & 89,5 & 0 & 0,0 \\
\hline Genel & 4 & 4,8 & 10 & 12,0 & 65 & 78,3 & 4 & 4,8 \\
\hline
\end{tabular}

İşletmelerin \%78,3'ünün 1996 - 2005 yılları arasında kurulduğu saptanmıştır. Bu durum işletmelerin büyük bir çoğunluğunun devlet desteği alınmaksızın kurulduğunu göstermektedir. Kümes kuruluşunda devlet desteği (KKDF) şeklinde, 1986 - 1995 yılları arasında yapılmıştır (14). Bu yıllar arasında kurulan işletme oranı \%12'dir. Kuruluş finansmanın sağlanmasıyla ilgili yetiştiricilerden alınan yanıtlar bu bulguları destekler niteliktedir. 


\section{İşletmelerde üretimin özelliklerine ilişkin genel bulgular ve değerlendirilmesi:}

Entegrasyona bağlı olarak üretim yapan 65 adet sözleşmeli hindi yetiştiriciliği işletmesinden elde edilen işletme ölçekleri itibariyle üretimin özelliklerine ilişkin genel bulgular Tablo 7'de yer almaktadır.

Tablo 7: İşletme ölçekleri itibariyle üretimin özelliklerine ilişkin genel bulgular

Table 7: General findings on the characteristics of production in terms of business scales

\begin{tabular}{|c|c|c|c|}
\hline & 2006 & 2007 & Değișim (\%) \\
\hline \multicolumn{4}{|l|}{ KÜÇÜK ÖLCCEKLİ İSSLTMELER } \\
\hline İșletme Sayısı & 22 & 22 & 0,0 \\
\hline Toplam Kapalı Alan $\left(\mathrm{m}^{2}\right)$ & 29.230 & 31.730 & 8,6 \\
\hline Toplam Yetiştirme Dönemi & 53 & 57 & 7,5 \\
\hline Ortalama Yetiştirme Dönemi & 2,41 & 2,59 & 7,5 \\
\hline Kümese Konulan Civciv/Palaz Sayısı (adet) & 121.880 & 131.028 & 7,5 \\
\hline Hindi Sayıs1 (adet) & 113.090 & 122.635 & 8,4 \\
\hline Ölüm Oranı (\%) & 7,2 & 6,4 & $-11,1$ \\
\hline Birim Alana Konulan Civciv Sayısı (baş/m²) & 4,17 & 4,13 & $-1,0$ \\
\hline Toplam CA (kg) & $1.336 .230,3$ & 1.270 .716 & $-4,9$ \\
\hline Ortalama CA $(\mathrm{kg})$ & 11,8 & 10,4 & $-11,9$ \\
\hline Toplam Yem Tüketimi (kg) & 3.496.328,1 & $3.207 .870,3$ & $-8,3$ \\
\hline Ortalama Yem Tüketimi (kg) & 30,9 & 26,2 & $-15,2$ \\
\hline Ortalama Kesim Yaşı (gün) & 120 & 109,7 & $-8,6$ \\
\hline Kapasite Kullanım Oranı (KKO) (\%) & 64,8 & 61,7 & $-4,8$ \\
\hline \multicolumn{4}{|l|}{ ORTA ÖLÇEKLİ İŞLETMELER } \\
\hline İşletme Sayıs1 & 21 & 21 & 0,0 \\
\hline Toplam Kapalı Alan $\left(\mathrm{m}^{2}\right)$ & 49.390 & 51.870 & 5,0 \\
\hline Toplam Yetiştirme Dönemi & 55 & 58 & 5,5 \\
\hline Ortalama Yetiştirme Dönemi & 2,62 & 2,76 & 5,3 \\
\hline Kümese Konulan Civciv/Palaz Sayısı (adet) & 268.737 & 285.390 & 6,2 \\
\hline Hindi Sayısı (adet) & 246.615 & 265.832 & 7,8 \\
\hline Ölüm Oranı (\%) & 8,2 & 6,9 & $-15,9$ \\
\hline Birim Alana Konulan Civciv Sayısı (baș/m²) & 5,44 & 5,50 & 1,1 \\
\hline Toplam CA $(\mathrm{kg})$ & $2.361 .057,4$ & $2.328 .530,9$ & $-1,4$ \\
\hline Ortalama CA $(\mathrm{kg})$ & 9,6 & 8,8 & $-8,3$ \\
\hline Toplam Yem Tüketimi (kg) & $5.836 .942,3$ & $5.593 .435,2$ & $-4,2$ \\
\hline Ortalama Yem Tüketimi (kg) & 23,7 & 21,0 & $-11,4$ \\
\hline Ortalama Kesim Yaşı (gün) & 113,2 & 107,4 & $-5,1$ \\
\hline Kapasite Kullanım Oranı (KKO) (\%) & 74,1 & 72,4 & $-2,3$ \\
\hline \multicolumn{4}{|l|}{ BÜYÜK ÖLÇEKLİ İȘLETMELER } \\
\hline İşletme Sayısı & 22 & 22 & 0,0 \\
\hline Toplam Kapalı Alan $\left(\mathrm{m}^{2}\right)$ & 98.190 & 101.140 & 3,0 \\
\hline Toplam Yetiştirme Dönemi & 52 & 54 & 3,8 \\
\hline Ortalama Yetiştirme Dönemi & 2,36 & 2,45 & 3,8 \\
\hline Kümese Konulan Civciv/Palaz Sayısı (adet) & 473.626 & 497.646 & 5,1 \\
\hline Hindi Sayıs1 (adet) & 428.388 & 459.183 & 7,2 \\
\hline Ölüm Oranı (\%) & 9,6 & 7,7 & $-19,8$ \\
\hline Birim Alana Konulan Civciv Sayısı (baș/m²) & 4,82 & 4,92 & 2,1 \\
\hline Toplam CA (kg) & $4.847 .084,6$ & $4.459 .450,0$ & $-8,0$ \\
\hline Ortalama CA $(\mathrm{kg})$ & 11,3 & 9,7 & $-14,2$ \\
\hline Toplam Yem Tüketimi (kg) & $12.298 .161,3$ & $10.883 .118,5$ & $-11,5$ \\
\hline Ortalama Yem Tüketimi $(\mathrm{kg})$ & 28,7 & 23,7 & $-17,4$ \\
\hline Ortalama Kesim Yaşı (gün) & 126,8 & 119,2 & $-6,0$ \\
\hline Kapasite Kullanım Oranı (KKO) (\%) & 72,4 & 67,1 & $-7,3$ \\
\hline
\end{tabular}


Araştırmada, 2006 yılına göre üretimde kullanılan toplam kapalı kümes alanının, ortalama devre, birim kapalı alana konulan civciv ve üretilen hindi sayısının 2007 yılında işletmeler genelinde arttı̆̆ı görülmektedir. Böyle bir durumda 2007 yılında toplam hindi üretiminde CA artışı olması gerektiği şeklinde bir beklenti oluşmaktadır. Ancak bu verilere karşın 2007 yılında KKO'nun, toplam ve ortalama hindi canlı ağırlığının 2006 yılına göre düştügü tespit edilmiştir. Elde edilen bu bulgular değerlendirildiğinde entegrasyonların 2007 yılında 2006 yılına göre maliyet düşürücü tedbirler aldıkları sonucu ortaya çıkmaktadır. Entegrasyonlar en büyük masraf unsuru olan yem masraflarında kesintiye gidebilmek için civciv maliyetini bir parça yükseltmek pahasına 2007 yılında ortalama kesim yaşını 10 gün azaltarak FCR değerlerini düşürmüşler, böylece daha düşük bir yem maliyetiyle üretim sürecini tamamlama yolunu seçmişlerdir. Ayrıca ortalama kesim yaşındaki 8 günlük azalma mortalite oranında \%17'lik bir düşüşe neden olmuştur ki bu durum, hem entegrasyonların hem de yetiştiricilerin kazancına olumlu yansımıştır. Bu hususta önemli bir olguda 2006 yılında sektörü önemli ölçüde etkileyen Kuş Gribi salgınıdır. Entegrasyonlar 2006 yılında Kuş Gribi nedeniyle bir dönem hindi etine cari talebin hiç olmaması nedeniyle stoklama masraflarını minimize etmek için, devre sürelerini uzatmak ve kullanmakta oldukları yem kalitesini ve maliyetini düşürmek temeline oturttukları bir kriz politikası yürütmüşlerdir. Entegrasyonların 2007 yılı üretiminin, 2006 yılı üretiminin altında kalmasında etmenlerden biri, Kuş Gribi salgının talepte yarattığı dramatik düşüş nedeniyle entegrasyonların her an oluşabilecek yeni bir zoonoz salgın ihtimaline karşı ihtiyatlı davranması, diğer sebepleri de 2007 yılından itibaren yem fiyatlarının ve yumurta/civciv maliyetlerinin yükselişe geçmesidir. Arıkan ve ark. (3) da belirttiği gibi, Türkiye'de etlik piliç yemi ve piliç eti fiyatları kısa dönemde eş bütünleşiktir ve fiyatlar yükselme/düşme bakımından birbirini takip etmektedir. Kapalı alan kullanımı, toplam yetiştirme dönemi, kümese konulan civciv sayısı 2007 yılında 2006 yılına göre, en çok küçük ölçekli işletmelerde artmıştır. KKO, toplam yem tüketimi ve toplam CA kriterleri bakımın 2007 yılında 2006 y1lına göre en büyük kaybın büyük ölçekli işletmelerde görüldüğü saptanmıştır. Her ne kadar burada ortaya çıkan sonuç entegrasyonlar tarafından küçük ölçekli işletmelere pozitif ayrımcılık yapıyormuş gibi görünmesine karşın, aslında durum tam olarak bu biçimde değerlendirilemez. Çünkü her ne kadar işletme sahibinin adı farklı da olsa, birbirine yakın küçük ve çok sayıda işletme, çevreden bağımsız tek başına bir büyük işletmeden entegrasyonlar için bir bütün olarak çok daha büyük bir işletme özelliği taşımaktadır. Entegrasyonlar genellikle birbirine yakın konumlanmış yetiştiricilerinin üretim planlamasını senkronize biçimde yapmaktadırlar. Bu sayede civciv, yem ve veteriner hekimlik hizmeti gibi nakliyat, akaryakıt ve işgücü maliyeti gerektiren ve entegrasyona ait masrafların azaltılması sağlanmış olmaktadır. Çalışmanın yürütülmesi sırasında elde edilen önemli bir gözlem de yetiştiricinin, entegrasyonun kesimhanesine yakınlığının, yetiştiricilik başarısına göre yetiştiricinin üretimde tercih edilirliğinde çoğu zaman daha etkin olduğu olgusudur. Türkiye'de özellikle ulaşım giderlerinin çalışmalarda belirleyici etki yapabileceği gerçeği, ileride yapılacak çalışmalarda göz ardı edilmemelidir.

\section{Teknik ve kısmi teknik değerlendirme rasyolarına ilişkin bulgular ve değerlendirilmesi:}

İşletme ölçekleri itibariyle kısmi teknik ve teknik değerlendirme rasyolarına ait bulgular sırasıyla Tablo 8 ve Tablo 9'da verilmiştir.

Tablo 8: İşletme ölçekleri itibariyle kısmi teknik değerlendirme rasyolarına ait bulgular

Table 8: Findings of partial technical indicators in terms of business scales

\begin{tabular}{lcccccccc}
\hline & \multicolumn{2}{c}{ Küçük } & \multicolumn{2}{c}{ Orta } & \multicolumn{2}{c}{ Büyük } & \multicolumn{2}{c}{ Genel } \\
& $\mathbf{2 0 0 6}$ & $\mathbf{2 0 0 7}$ & $\mathbf{2 0 0 6}$ & $\mathbf{2 0 0 7}$ & $\mathbf{2 0 0 6}$ & $\mathbf{2 0 0 7}$ & $\mathbf{2 0 0 6}$ & $\mathbf{2 0 0 7}$ \\
\hline Kısmi Teknik Verimlilik Yem & 0,427 & 0,442 & 0,451 & 0,463 & 0,434 & 0,453 & 0,437 & 0,453 \\
Kısmi Teknik Verimlilik issgücü & 228,4 & 211,5 & 382,4 & 379,5 & 539,9 & 513,5 & 412,6 & 395,7 \\
\hline
\end{tabular}


Tablo 9: İşletme ölçekleri itibariyle teknik değerlendirme rasyolarına ait bulgular

Table 9: Findings of technical indicators in terms of business scales

\begin{tabular}{lcccccccc}
\hline & \multicolumn{2}{c}{ Küçük } & \multicolumn{2}{c}{ Orta } & \multicolumn{2}{c}{ Büyük } & \multicolumn{2}{c}{ Genel } \\
& $\mathbf{2 0 0 6}$ & $\mathbf{2 0 0 7}$ & $\mathbf{2 0 0 6}$ & $\mathbf{2 0 0 7}$ & $\mathbf{2 0 0 6}$ & $\mathbf{2 0 0 7}$ & $\mathbf{2 0 0 6}$ & $\mathbf{2 0 0 7}$ \\
\hline Ortalama Kesim Yaşı (gün) & 120,0 & 109,7 & 113,2 & 107,4 & 126,8 & 119,2 & 119,9 & 111,9 \\
Yaşama Oranı (\%) & 92,8 & 93,6 & 91,8 & 93,1 & 90,4 & 92,3 & 91,2 & 92,7 \\
Ölüm Oranı (\%) & 7,2 & 6,4 & 8,2 & 6,9 & 9,6 & 7,7 & 8,8 & 7,3 \\
Ortalama CA (kg) & 11,8 & 10,4 & 9,6 & 8,8 & 11,3 & 9,7 & 10,8 & 9,5 \\
FCR & 2,615 & 2,522 & 2,484 & 2,417 & 2,569 & 2,474 & 2,557 & 2,472 \\
AVF & 374,99 & 368,97 & 363,83 & 369,69 & 365,51 & 346,94 & 368,18 & 361,75 \\
\hline
\end{tabular}

İşletmeler genelinde kuru madde olarak $1 \mathrm{~kg}$ yem ile elde edilen et, 2007 yılında 2006 yılına göre $16 \mathrm{~g}(\% 3,7)$ artarak 453 g'a ulaşmıştır. İşletme ölçekleri bakımından yemin kısmi verimliliğinde en büyük artış \%4,4 ile büyük ölçekli işletmelerde görülmüştür. Yemin kısmi teknik verimliliği, özellikle kullanılan yemin kalitesi ve kesim yaşı ile yakın ilişkilidir. Bunun yanında yetiştiricilik becerisi, ölüm oranı gibi kriterler de bu rasyo üzerine etkindir. Bu nedenle yemin kısmi teknik verimliliği için, genel olarak belirli illerde belirli entegrasyonların bulunması ve bu entegrasyonların birbirinden farklı kalitede yemler hazırlaması bakımından, iller üzerinden yapılacak değerlendirme daha önemli sonuçlar vermektedir.

İşgücü kısmi teknik verimliliğinin 2007 yılında işletmeler genelinde $\% 4,1$ oranında düştüğü tespit edilmiştir. İşü̈cü kısmi teknik verimliliğinde 2007 yılında en büyük değer kaybı ölçekler itibariyle \%7,4 ile küçük ölçekli işletmelerde yaşanmıştır. Ölçekler itibariyle işgücünün teknik verimliliğinde tüm işletme ölçekleri bakımından düşüş olduğu tespit edilmiştir.

Teknik değerlendirme rasyoları içinde yer alan kesim yaşı, ortalama CA, FCR ortalama değerlerinin ölçekler itibariyle büyük farklılıklar gösterdiği dikkat çekmektedir. Bu değerlerin ölçekler bakımından bu kadar farklı olmasının temelinde çok değişkenli bir ilişkinin varlığı yatmaktadır. Bu üç kriter; hayvanın ırkı, cinsiyeti, yem kalitesi ve yetiştiricilik becerisine göre büyük değişkenlik gösterebilmektedir.

İşletmeler genelinde ortalama kesim yaşının 2007 yılında 2006 yılına göre 8 gün kısalarak (\%6,7) 119,9 günden 111,9 güne düştüğü Tablo 8'de görülmektedir. Kesim yaşı süresinin ölçekler itibariyle yaklaşık 11 günle $(\% 8,6)$ en çok küçük ölçekli işletmelerde kısaldığı tespit edilmiştir.

Ortalama kesim yaşında Kuş Gribi krizinin görüldüğü 2006 yılı ile diğer yıllar arasında değişim, Yalçın ve ark. (17)'nın çalışmasından elde edilen oransal değer ile örtüşmektedir.

İşletmeler genelinde 2007 yılında 2006 yılına göre yaşama gücünün yükseldiği, ölüm oranının düştüğü saptanmıştır. İşletmeler genelinde ölüm oranının 1,5 puan azalarak \%8,8'den \%7,3'e düştüğü, yaşama oranının da aynı miktarda artarak \%91,2'den \%92,7'ye çıtı̆̆ belirlenmiştir. Ölçekler itibariyle ölüm oranında en büyük azalma büyük ölçekli işletmelerde (1,9 puan), en küçük değişiminde küçük ölçekli işletmelerde olduğu ( 0,8 puan) bulunmuştur. Ölüm oranındaki düşüşün ortalama kesim yaşı ve KKO'da tespit edilen azalma ile ilişkili olduğu düşünülmektedir. Entansif beside kullanılan bu hindiler olabilecek en az yemle en kısa zamanda olabilecek en yüksek miktarda et üretmektedirler. Hızlı gelişim; iskelet problemleri, solunum ve kardiyovasküler sistem hastalıklarına yol açmaktadır (9). Bu nedenle kesim yaşı arttıkça hindilerde belirtilen hastalıklara duyarlılık artmaktadır. Ölçekler itibariyle büyük ölçekli işletmelerde ölüm oranında azalmanın en fazla oluşunun belirtilen işletmelerin bu kriter bakımından halihazırda en yüksek değere sahip olmalarından kaynaklandığı düşünülmektedir. Ölüm oranı kriteri bakımından büyük ölçekli işlemelerin en yüksek değere sahip olmasının nedeninin, işletme ölçeğinin büyümesiyle işletme idaresinin ve yetiştiriciliğin giderek zor hale gelmesi olduğu düşünülmektedir.

İşletmeler genelinde ortalama canlı ağılı̆̆ın, ortalama kesim yaşının kısalmasına paralel olarak 2007 yılında 2006 yılına göre 1,3 kg azaldığı ve 9,5 kg olduğu belirlenmiştir. Ortalama CA’ta 2006 yılına göre 2007 yılında ölçekler 
itibariyle azalmanın en az orta ölçekli işletmelerde $(0,8 \mathrm{~kg})$, en fazla büyük ölçekli işletmelerde $(1,6 \mathrm{~kg})$ olduğu tespit edilmiştir. Azalmanın en fazla büyük ölçekli işletmelerde olmasının bu işletmelerdeki hindilerin ortalama canlı ağırlığının diğer ölçeklere göre yüksek olmasıyla açıklanması söz konusu değildir. Çünkü küçük ölçekli işletmelerde kesim yaşına gelmiş hindilerin ortalama canlı ağırlı̆̆ı, diğer işletmelere göre yüksek olmasına karşın ortalama CA'ta düşüş en yüksek değere sahip değildir. Ortalama CA üzerinde pek çok faktör etkili olabilmektedir. Bunlardan belli başlıları; kesim yaşı, hindi cinsiyeti, hindi ırkı, yetiştiricilik becerisi ve yem kalitesi olarak sıralanabilir. Ortalama canlı ağırlığın 2007 yılında 2006 yılına göre ölçekler itibariyle düşüşünde kesim yaşının azalmasının yanında belirtilen diğer etmenlerin olumsuz etkisinin en çok büyük ölçekli işletmelerde toplandığı söylenebilir.

FCR' da 2007 yılında 2006 yılına göre \%3,3 oranında bir düşüş yaşandığı ve FCR'ın 2,472 olarak şekillendiği tespit edilmiştir. FCR'daki bu değişim verimlilik artışından ziyade, kesim süresindeki azalmadan kaynaklanmaktadır. Hindi yetiştiriciliğinde kesim süresi azaldıkça FCR da küçülmektedir. Ortalama kesim ağırlı̆̆nı belirleyen etmenler FCR üzerinde de etkilidir. Bu nedenle işletme ölçekleri ve iller bakımından FCR değerleri değişimleri tam olarak kesim yaşındaki değişimlere paralellik göstermemektedir.

FCR bakımından Kuş Gribinin görüldügü 2006 yılı verileri, Yalçın ve ark. (17)'nın 2006 yılı verileri ile birebir örtüşmektedir. Bu çalışmada tespit edilen 2007 yılı FCR verilerinin Yalçın ve ark. (17)'nın 2005 yılı verilerine göre daha düşük olduğu söylenebilir.

AVF'nin 2007 yılında 2006 yılına göre \%1,7 oranında düştüğü görülmektedir. AVF; ortalama CA ve yaşama oranıyla doğru orantılı, FCR ve kesim yaşı ile ters orantılıdır. Bu bakımdan AVF'yi FCR'ın azalmış, kesim yaşının düşmüş ve yaşama oranının yükselmiş olması olumlu yönde etkilerken, başlı başına ortalama CA'ta meydana gelen düşüş AVF'nin işletmeler genelinde düşmesine neden olmuştur. AVF'deki düşüş, işletmeler genelinde verimliliğin bir parça düştügünü göstermekle birlikte daha önce belirtildiği üzere kârlılığı olumsuz yönde etkilememiştir.

\section{İşletme sonuçları ve maliyetlere ilișkin bulgular ve değerlendirilmesi:}

Araştırmada kapsamına alınan işletmelerin masraf kalemleri ve $1 \mathrm{~kg}$ hindi eti CA maliyetleri Tablo 10'da özetlenerek sunulmuştur.

Tablo 10: Girdi unsurlarının masraflar genel toplamı içerisindeki yüzde payları ve hindi eti kg CA maliyeti

Table 10: Percentage of input items in the total costs and kg live weight cost of turkey

\begin{tabular}{lcccc}
\hline Girdi Kalemleri & Küçük & Orta & Büyük & Genel \\
\hline Yem Maliyeti & 73,8 & 73,9 & 75,3 & 74,3 \\
Civciv - Palaz Maliyeti & 11,7 & 12,6 & 10,7 & 11,7 \\
Amortisman Masrafları & 4,0 & 4,1 & 4,1 & 4,1 \\
Genel İdare Masrafları & 2,7 & 2,7 & 2,7 & 2,7 \\
Bakım Onarım Masrafları & 2,2 & 2,1 & 2,1 & 2,2 \\
Isıtma - Aydınlatma Maliyeti & 2,1 & 2,0 & 2,2 & 2,1 \\
Altlık Maliyeti & 1,5 & 1,0 & 1,3 & 1,3 \\
Diğer Masraflar & 2,0 & 1,6 & 1,6 & 1,8 \\
\hline 2006 Yılı Hindi eti kg CA maliyeti, TL (\$) & $2,022(1,406)$ & $2,021(1,405)$ & $1,969(1,369)$ & $2,004(1,394)$ \\
2007 Yılı Hindi eti kg CA maliyeti, TL (\$) & $2,087(1,596)$ & $2,071(1,584)$ & $2,027(1,550)$ & $2,062(1,577)$ \\
\hline
\end{tabular}

İşletmeler genelinde hindi eti kg CA maliyetinin 2007 yılında 2006 yılına göre enflasyondan arındırılarak yapılan hesaplamada \%2,9 oranında arttığı tespit edilmiştir. Maliyet artışının büyük ölçüde yem maliyetindeki ve hindi yumurta maliyetindeki artıştan kaynaklandığı söylenebilir. Ölçekler itibariyle değerlendirmede büyük ölçekli işletmelerde hindi eti CA maliyetinin en düşük, küçük ölçekli işletmelerde ise en yüksek seviyede olduğu tespit 
edilmiştir. Genel ekonomi kuralları gereği, ölçek büyüdükçe ısıtma-aydınlatma, su, veteriner hekim - sağlık gibi değişken masrafların birim maliyetinin düştüğü gerçeğini, ortaya çıan sonuçlar da desteklemektedir.

\section{Rantabilite rasyolarına ilişkin bulgular ve değerlendirilmesi:}

İşletmelerde performansın en önemli göstergelerinden birisi kârlılık rasyolarıdır. Entegrasyonlara bağlı sözleşmeli hindi yetiştiriciliği işletmelerinin kârlılıkları ve rantabilite rasyoları ayrı ayrı hesaplanmıştır (Tablo11).

Tablo 11: İşletme ölçeklerine göre rantabilite rasyolarına ilişkin bulgular

Table 11: Findings on profitability ratios according to business scales

\begin{tabular}{lcccccccc}
\hline & \multicolumn{2}{c}{ Küçük } & \multicolumn{2}{c}{ Orta } & \multicolumn{2}{c}{ Büyük } & \multicolumn{2}{c}{ Genel } \\
& $\mathbf{2 0 0 6}$ & $\mathbf{2 0 0 7}$ & $\mathbf{2 0 0 6}$ & $\mathbf{2 0 0 7}$ & $\mathbf{2 0 0 6}$ & $\mathbf{2 0 0 7}$ & $\mathbf{2 0 0 6}$ & $\mathbf{2 0 0 7}$ \\
\hline Mali Rantabilite & 0,120 & 0,123 & 0,119 & 0,129 & 0,141 & 0,143 & 0,127 & 0,132 \\
Rantabilite Faktörü & 0,157 & 0,165 & 0,158 & 0,171 & 0,179 & 0,189 & 0,165 & 0,175 \\
O/I Oranı & 1,19 & 1,20 & 1,19 & 1,21 & 1,22 & 1,24 & 1,20 & 1,22 \\
\hline
\end{tabular}

İşletmeler geneli itibariyle entansif hindi yetiştiriciliği işletmelerinin mali rantabilitelerinin 2007 yılında 2006 yılına göre \%3,9 oranında daha yüksek olduğu bulunmuştur. Ölçekler itibariyle mali rantabilitede 2006 yılına göre 2007 y1lında en fazla yükselmenin \%8,4 ile orta ölçekli işletmelerde olduğu saptanmıştır. Ancak mali rantabilitesi en yüksek olan işletmeler büyük ölçekli işletmelerdir. Büyük ölçekli işletmelerin mali rantabilitesinin orta ölçekli işletmelerin mali rantabilitesinden 2006 yılında \%16, 2007 yılında \%10; küçük ölçekli işletmelerin mali rantabilitesinden 2006 yılında \%15, 2007 yılında \%14 daha yüksek olduğu tespit edilmiştir. Bu bulgular 1şığında özsermayenin ölçekler itibariyle büyük ölçekli işletmelerde diğer ölçeklere göre çok daha kârlı olduğu görülmektedir. İşletmeler genelinde mali rantabilitenin 2007 yılında az da olsa artması 2006 yılında Kuş Gribi’nin olumsuz etkilerinin mali anlamda sektörün üzerinden kalkmaya başladığını göstermektedir.

Safi Hâsılanın Gayri Safi Hâsılaya oranını gösteren rantabilite faktörü 2007 yılında 2006 yılına göre \%6,1 artmıştır. İşletme ölçeği büyüdükçe rantabilite faktörünün de arttığı, büyük ölçekli işletmelerde en yüksek değere sahip olduğu saptanmıştır. Küçük ölçekli işletmelerin rantabilite faktörünün büyük ölçekli işletmelere göre 2006 yılında \%12, 2007 yılında \%13 daha düşük değere sahip olduğu tespit edilmiştir. Orta ölçekli işletmelerin rantabilite faktörünün büyük ölçekli işletmelere göre 2006 yılında \%12, 2007 yılında \%10 daha düşük değere sahip olduğu belirlenmiştir. Bu durum büyük ölçekli işletmelerde sermayenin daha verimli olarak kullanıldığını ve işletmelerin etkin olarak çalıştıklarını ortaya koymaktadır.

İşletmelerde verimliliği gösteren diğer bir rasyo da O/I oranıdır. Belli bir girdi miktarına tekabül eden çıktı miktarının belirli bir dönemde artması, işletmenin verimliliği bakımından istenilen bir durumdur. İşletmelerin verimliliğinin denetlenmesi bakımından da $\mathrm{O} / \mathrm{I}$ oranı sağlam bir denetim aracı olabilir.

O/I oranı işletmeler genelinde 2006 ve 2007 y1lında sırasılyla 1,20 ve 1,22 olarak bulunmuştur. Bu oran; Nijerya'daki hindi işletmelerinde yürütülen çalışmada 1,539 (4) olarak saptanmıştır.

$\mathrm{O} / \mathrm{I}$ oranı işletmeler genelinde 2007 yılında 2006 yılına göre $\% 1,7$ artmıştır. O/I oranı, işletmelerde verimliliğin tanımları arasında önemli rasyolardan biri olduğu için yıllık verimlilikte \%1,7'lik artış önemli bir verimlilik artışı olarak nitelenebilir. İşletme ölçekleri bakımından O/I oranın büyük ölçekli işletmelerde, küçük ölçekli işletmelere göre \%3,2 ve orta ölçekli işletmelere göre \%2,4 yüksek olduğu bulunmuştur. Bu gösterge ölçeğin büyüklüğünün artmasıyla işletme verimliliği arasında ilişki olduğunu göstermesi bakımından önemlidir. 


\section{Kârlılık ve verimlilik analizlerine ilişkin bulgular ve değerlendirilmesi:}

Tüm işletmeler itibariyle basamaklı (stepwise) regresyon metoduyla tahmin edilen model sonuçları ve ilgili istatistik testleri Tablo 12 'de verilmiştir.

Tablo 12: Tüm işletmeler itibariyle regresyon katsayı tahmin sonuçları ve istatistiksel testler

Table 12: Regression coefficient estimation results and statistical tests for all enterprises

\begin{tabular}{lrrrrrrr}
\hline & \multicolumn{1}{c}{ N } & \multicolumn{1}{c}{ BETA } & \multicolumn{1}{c}{ T } & \multicolumn{1}{c}{ P } & ADJ. $\mathbf{R}^{2}$ & \multicolumn{1}{c}{ F } & P \\
\hline$\beta_{0}$ & & 0,016 & 0,591 & 0,555 & 0,997 & 12290,161 & $<0,001$ \\
$\mathrm{X}_{5}$ & 329 & $-0,963$ & $-212,528$ & 0,000 & & \\
$\mathrm{X}_{6}$ & 329 & $-0,986$ & $-179,965$ & 0,000 & & \\
$\mathrm{X}_{2}$ & 329 & $-0,987$ & $-58,270$ & 0,000 & & \\
$\mathrm{X}_{1}$ & 329 & 0,988 & 89,986 & 0,000 & & \\
$\mathrm{X}_{3}$ & 329 & $-1,059$ & $-45,782$ & 0,000 & & \\
$\mathrm{X}_{7}$ & 329 & $-0,960$ & $-18,370$ & 0,000 & & \\
$\mathrm{X}_{8}$ & 329 & $-0,755$ & $-12,326$ & 0,000 & & \\
$\mathrm{X}_{4}$ & 329 & $-0,018$ & $-6,074$ & 0,000 & & \\
\hline Y=Kâr(TL/kgCA) & & & &
\end{tabular}

Yapılan bu ekonomik değerlendirmeler sonucunda, entegrasyona bağlı hindi yetiştiricilerinin 2006-2007 yıllarına ait verilerine uygulanan çoklu regresyon analizi yardımıyla, işletmelerin birim karlılığına masraf unsurlarının etkisi tespit edilmeye çalışılmıştır.

Bağımsız değişkenlerin her birinin bağımlı değişken üzerindeki etkilerinin istatistik önemini açıklayan $\mathrm{t}$ değerlerine göre; tüm işletmeler bazında bağımlı değişken olan kâra; canlı hindi satış fiyatı, civciv/palaz maliyeti, 1sıtma-aydınlatma masrafları, işçilik, kuru madde cinsinden kesif yem masrafi, toplam diğer masraflar, veteriner hekim, sağlık, dezenfeksiyon ve temizlik masrafları ile FCR değişkenlerinin etkisinin istatistik açıdan önemli $(\mathrm{P}<0,01)$ olduğu tespit edilmiştir.

İşletmeler genelinde $\mathrm{R}^{2}$ Belirtilen Tanımlayıcılık Katsayısı \%99,7 olarak tespit edilmiş olup, işletmelerin birim kârlılığındaki değişimin en az \%99'u her bir değerlendirme kriteri bakımından modele dâhil edilen canlı hindi satış fiyatı, civciv/palaz maliyeti, 1sıtma-aydınlatma masrafları, işçilik, kuru madde cinsinden kesif yem masrafı, toplam diğer masraflar, veteriner hekim, sağlık, dezenfeksiyon ve temizlik masrafları ile FCR değişkenleri tarafindan açıklanmaktadır. Oluşturulan modelin F değeri, F tablo değerinden büyük bulunmuştur. O nedenle, gruplar arası farkın rastgele ortaya çıkma ihtimali yüzde 1'den daha az olan modelin $\mathrm{F}$ değeri, istatistiksel olarak önemli $(\mathrm{P}<0,001)$ bulunmuş olup, bu durum modelin kabul edilebilirliğini göstermektedir.

İşletmeler geneli itibariyle ortaya çıkan regresyon modelleri incelendiğinde kuru madde cinsinden kesif yem masrafinın (X5) birim kâr üzerine negatif yönlü olarak en yüksek ilgiye sahip olduğu görülmektedir. Kuru madde cinsinden kesif yem masrafinda (X5) meydana gelen \%1'lik artışın, kg CA başına elde edilen kârda işletmeler geneli itibariyle yaklaşık \%0,943 azalışa neden olduğu bulunmuştur.

\section{Tartışma ve Sonuç}

Bu çalışmaya karar verildiğinde, Türkiye'de etlik piliç sektörüne göre entansif yetiştiricilikte geçmişi oldukça yeni sayılan hindi yetiştiriciliğinin, piliç etine göre sunduğu alternatif lezzet, sağlıklı beslenme trendinin vazgeçilmez bir parçası olması sebebiyle piliç sektöründen farklı bir tüketici kitlesine hitap edeceği ve hindi üretiminin, çalışmanın 
yürütüldüğü yıllarda hızla artacağı beklentisi bulunmaktaydı. Ancak Türkiye'de ilk vakaları 2005 yılı sonlarında görülen ve sonrasında 2006 yılında yaşanan insan ölümleriyle halk üzerinde büyük bir kaygı oluşturan Kuş Gribi krizi ve yem ham maddesinde yaşanan olağan dışı artışlar, bu çalışmanın beklentilerini, yönünü ve sonuçlarını da etkilemiştir. Öyle ki çalışmanın tamamlanmakta olduğu 2010 yılı içerisinde dahi hindi yetiştiriciliği Türkiye'de 2005 yılı üretim seviyelerine ulaşamamıştır.

Kuş Gribi gerçeği, et sektöründe ölümcül zoonoz bir hastalığın tüketici tercihlerini nasıl etkileyebileceğini göstermesi bakımından çok önemli bir deneyim olmuştur. Zira çalışmanın yapıldığı yıllarda Türkiye'de tüketicinin yeni yeni tanıştığı ve alışmaya başladığı entansif hindi etinin tüketimi, Kuş Gribi ile birlikte hızla düşüşe geçmiş ve geçmişten gelen güçlü bir alışkanlık olmadığı için de toparlanması etlik pilice göre daha fazla vakit almıştır.

$\mathrm{Bu}$ dönemde sektörü son derece olumsuz etkileyen bir durum da hindi yeminin çok önemli bir bölümünü oluşturan soya ve mısır birim fiyatındaki önemli artışlardır. Yapılan çalışmalar bu artışların kanatlı yetiştiriciliğinde maliyet kalemleri içinde yem masrafları kaleminin oranını \%50'lerden \%70'lere çıkardığını göstermiştir (8). Nitekim hindi yetiştiriciliğinde yem maliyetlerinin maliyet kalemleri içindeki payı Türkiye'de 2006 yılında \% 75,5; 2007 yılında \%73 olarak tespit edilmiştir. Yem maliyetlerinin bu kadar arttığı ve yem masraflarını azaltmanın bir o kadar önem kazandığı ülkemiz koşullarında entegrasyonlara kesim yaşını düşürmeleri önerilebilir. Özellikle ilerleyen günlerde FCR oranı çok yüksek olan dişi hindilerde kesim yaşının düşük tutulmasının FCR'ın azalmasına ve maliyetlerin düşürülmesine olumlu katkıda bulunacağı düşünülmektedir. Aynı zamanda yem maliyetlerinin yükselmesi fiyatı sabit bile olsa görece olarak civciv maliyetlerini düşüreceği için yine entegrasyonların birim alana koydukları civciv sayını da artırması yetiştiricilikte kârlılığı artırabilecek bir diğer strateji olabilir. Bu iki öneri bir arada uygulanırsa kesim yaşı düşürüldüğü için FCR'ın düşeceği ve yem maliyetlerinde önemli bir azalmanın olacağı buna karşılık birim alana konulacak hindi sayının artırılarak FCR'da kesim yaşının azaltılmasıyla meydana gelen azalmanın bir miktar telafi edileceği düşünülmektedir.

Hindi yetiştiriciliğinde bunca olumsuz etmenin bir araya geldiği 2006 - 2007 yılları arasında gerçekleştirilen bu çalışmada bile Türkiye'de entansif hindi yetiştiriciliği işletmelerinin rantabl olduğu ortaya çıkmıştır. Sektörün O/I oranının her şeye rağmen kâra geçiş noktası olan 1 değerinin üzerinde, 2006 yılında 1,20; 2007 yılında 1,22 olduğu saptanmıştır. Sektörde mali rantabilite ve rantabilite faktörü değerlerinin de olumlu olduğu ve 2006 yılına göre 2007 yılında yükseldiği tespit edilmiştir. O/I oranı, mali rantabilite ve rantabilite faktörü değerlerinin işletme ölçekleri bakımından büyük ölçekli işletmelerde en yüksek değere sahip olduğu saptanmıştır. İşletme ölçekleri bakımından büyük ölçekli işletmelerin, hem $\mathrm{O} / \mathrm{I}$ oranı, hem mali rantabilite hem de rantabilite faktörü yönünden diğer işletme ölçeklerine göre yüksek çıkması işletme verimliliğinin, özsermayenin kârlılığının ve sermayenin verimliliğinin büyük ölçekli işletmelerde daha yüksek olduğunu göstermiştir. Elde edilen sonuçlar değerlendirildiğinde, entegrasyonların büyük ölçekli yetiştiricileri teşvik etmelerinin sektörün ve kendilerinin gelişimine, kârlılığına ve verimliliğine olumlu katkı yapacağı söylenebilir.

Entansif yetiştiriciliğin Türkiye'de karşılaştığı büyük darboğazlardan birinin yaşandığı 2006 - 2007 yıllarında yürütülmüş bu çalışmadan, işletme kârlılık ve verimliliklerine yönelik elde edilen bulgular, sektörün geleceğinin umut verici olduğunu göstermektedir. Bu zor koşullara rağmen yetiştiriciliğin rantabl olduğunun tespiti, Kuş Gribi, Domuz Gribi gibi tüketicinin hindi eti tüketim kararını olumsuz yönde etkileyen koşullar ortadan kalktığında ve talep tekrar yükselişe geçtiğinde sektörün kârlılı̆̆ının çok daha yüksek olabileceğini göstermektedir. Sektörde entegrasyona bağlı sözleşmeli yetiştiricilerin KKO'nun \%70 dolayında olması bir üretim döneminde dahi hindi eti üretiminin sektör tarafından \%30 artırılabileceğine işarettir. Ayrıca entegrasyonların kesimhane kapasitelerinin güncel üretiminin çok daha üzerinde bulunuyor olması, kazancın iyi olduğu dönemlerde sözleşmeli piliç yetiştiricilerinden sağlanacak takviye yetiştiricilerle üretimin çok daha yüksek miktarlara çıarılabileceğini göstermektedir.

Sektörün gelişiminde tüketici tercihleri belirleyici olacaktır. Efektif talep ve kişi başına tüketim ancak hindi eti tüketiciye cazip gelecek bir değere ulaştığında önemli ölçüde artabilecektir. Bu nedenle sektör tüketici talebini artırmak için, fiyat düşürücü tedbirleri almak başta olmak üzere, hindi etinin servis edilebilirliğini, sağlık şartlarını, tadını ve lezzetini geliştirmeye yönelik çalışmalara odaklanmalıdır.

Yapılan regresyon analizi sonucunda hindi yemi fiyatının kâr üzerindeki etkisinin son derece yüksek olduğu (yem fiyatında \%1'lik artış kârlılıkta \%0,96'lık azalma oluşturmakta) görülmüsşür. Hindi yeminin temel unsurları olan 
soyanın büyük bölümü ve mısırın bir bölümü yurtdışından sağlanmaktadır. Bu ürünlerden özellikle mısırın yakıt olarak kullanımının artması hammaddenin birim fiyatını petrol fiyatlarına indeksli olarak yükseltmektedir. Nitekim 2000 yılında ithal edilen mısırın fiyatı 110 \$/ton iken, 2007 yılında 229,4 \$/ton'a ve 2008 yılında da 314,1 \$/ton'a ulaşmıştır. 2000 yılında 214,2 \$/ton olan soya küspesinin fiyatı da yükselerek 2007 yılında 287,4 \$/ton'a, 2008 yılında da 440,6 \$/ton'a ulaşmıştır (16). Özellikle 6 haftalık yaşın üzerindeki hindilerde çeşitli enzim katkılarıyla mısır ve soyaya alternatif, daha uygun fiyatlı rasyonların hazırlaması yem maliyetlerini düşürmek ve işletme kârlılığı bakımından faydalı olabilir. Yine hindi entegrasyonları ile hammadde sağlayıcıları arasındaki ilişkinin geliştirilerek daha uygun fiyata daha uygun kalitede ürünün tedarik edilmesi sağlanmaya çalışılmalıdır.

Hindi yetiştiriciliğinde belli bir girdi karşısında elde edilen çıktı miktarı sürekli artmaktadır, yani sektörün verimliliği sürekli yükselmektedir. Uygun besleme, yem formülasyonlarının gelişimi ve içeriğinin kalitesinin artması gibi ilave diğer gelişmeler sayesinde hindi yetiştiriciliğinde ticari performansın daha çok artırılabileceği söylenebilir.

Hindi yetiştiriciliğinin ticari performansı üzerinde yetiştiricilerin bakım koşulları da oldukça önemlidir. Yetiştiricilerin barınma, beslenme, yönetim ve organizasyon konusunda sürekli eğitim seminerleri almaları, yetiştiricilik hakkında güncel bilgilendirmelerin paylaşımının performansı ve kârı artırıcı etki yapacağı düşünülmektedir. Regresyon analizi sonucunda yakıt, yem, FCR, veteriner hekim - sağlık gibi kâr üzerinde oldukça etkili olduğu tespit edilen değişkenler, büyük ölçüde yetiştiricilerin bakım, yönetim ve organizasyon becerisine bağlı değişkenlerdir. Bu konuda alınacak eğitimin kârı önemli ölçüde artıracağı öngörülmektedir. Günümüze kadar yapılan çalışmaların daha çok damızlık hindilerde verimlilik artırışı üzerine yoğunlaştığı görülmektedir. Ancak bu çalışmada yapılan regresyon analizlerinin de gösterdiği gibi ticari performans üzerine yetiştirici bakım faaliyetleriyle doğrudan ilgili değişkenlerin önemli ölçüde etki ediyor olması, yönetim ve organizasyon üzerinde yapılacak düzenlemelerle ticari kârlılıkta, verimlilik üzerine yapılan uygulamalardan da çok artış sağlanabileceğini ortaya koymaktadır.

Sözleşmeli hindi yetiştiricilerine yapılabilecek en somut önerilerden biri de, işletme ölçeklerinin artırılmasıdır. Çalışma bulgularının da gösterdiği gibi büyük ölçekli işletmelerde hem O/I oranının, hem mali rantabilitenin hem de rantabilite faktörünün değeri, diğer ölçeklere göre oldukça yüksektir. Yetiştiricilerin gelirlerini ve kârlarını artırabilmede kendi değişken maliyetlerini en başarılı biçimde yönetme ve bakımını yaptıkları hindileri en uygun biçimde yetiştirmek dışında geriye kalan en sağlam alternatif işletme ölçeklerini artırmaktır. İşletme ölçeklerini artırmak yetiştiricilere, bakım koşulları sabit kalsa bile birim alana düşen değişken masrafların maliyetini azaltacağ 1 için daha kârlı yetiştiricilik yapma imkânı sağlayacaktır.

Dünya etlik piliç üretiminde ilk 15 ülke arasında yer alarak gösterilen başarının hindi yetiştiriciliğinde de gösterilebilmesi için ülkemizde gerekli altyapı, yetişmiş eleman ve potansiyel mevcuttur. Ülkede hindi tüketimi üzerinde olumsuz etkisi olan hastalıklar ve yüksek seyirli yem fiyatlarının baskısı kalktığında, hindi yetiştiriciliğinin de tırmanışa geçerek hak ettiği konuma ulaşacağına inanılmaktadır.

\section{Çıkar Çatışması Beyanı}

Makalenin yazarları olarak herhangi bir kişisel ve finansal çıkar çatışması olmadı̆̆ını tasdik ederiz.

\section{Finansal Kaynak Beyanı}

$\mathrm{Bu}$ çalışma sırasında, yapılan araştırma konusu ile ilgili doğrudan bağlantısı bulunan herhangi bir ilaç, firmasından, tıbbi alet, gereç, ve malzeme sağlayan ve/veya üreten bir firma veya herhangi bir ticari firmadan, çalışmanın değerlendirme surecinde, çalışma ile ilgili verilecek kararı olumsuz etkileyebilecek maddi ve/veya manevi herhangi bir destek alınmamıştır.

\section{Yazar Katkısı Beyanı}

Fikir/kavram: Yavuz CEVGER

Deney tasarımı: Yavuz CEVGER

Denetleme/Danışmanlık: Yavuz CEVGER

Veri toplama: Cevat SIPAHI

Veri analizi ve yorum: Cevat SİPAHI 
Kaynak taraması: Cevat SIPAHI

Makalenin yazımı: Cevat SIPAHI

Eleştirel inceleme: Yavuz CEVGER

\section{Etik Onay}

$\mathrm{Bu}$ makaledeki sunulan verilerin, bilgilerin ve dokümanların akademik ve etik kurallar çerçevesinde elde edildiği, tüm bilgi, belge, değerlendirme ve sonuçlarının bilimsel etik ve ahlak kurallarına uygun olarak sunulduğuna dair yazarlardan etik beyan alınmıştır.

\section{Kaynaklar}

1. Anonim (2007): BESD-BİR Genel Sekreteri Yüce CANOLER'den elde edilen veriler. Görüşme Tarihi: 08.03.2007.

2. Anonim (2008): BESD-BİR Genel Sekreteri Yüce CANOLER'den elde edilen veriler. Görüşme Tarihi: 18.05.2008.

3. Arıkan MS, Çevrimli MB, Akın AC, Mat B, Tekindal MA (2019): Cointegration analysis of broiler meat and broiler feed prices in Turkey. Eurasian J Vet Sci, 35(4), 210-216.

4. Ayala MK, Nwagu BI, Sekoni AA, Adesehinwa AOK (2007): The profitability of turkey production in Zaira, Kaduna State, Nigeria. Asian J Inform Tech, 6(1), 27-33.

5. Cevger Y (2003): Quantitative methods to determine factors affecting profits of lamb fattening enterprises. Veterinární medicína, 48(1-2), 25-31.

6. Cevger Y, Türkyılmaz MK (2001): Türkiye'de hindi eti ve önemi. Vet Hekim Der Derg, 70(3).

7. Çıngı H (1990): Örnekleme Kuramı. Hacettepe Üniversitesi Fen Fakültesi Basımevi, Beytepe/Ankara.

8. Donohue M, Cuningham DL (2009): Effects of grain and oilseed prices on the costs of US poultry production. $\mathrm{J}$ Appl Poult Res, 18, 325 - 337.

9. Duncan IJH (2004): Welfare problems of poultry. 307-324. In: Benson JB, Rollin BE (Eds.) The Well-Being of Farm Animals, Ames, IA, Blackwell, 2004.

10. Fulginiti EL (1996): The change from red to white meat: The role of technology. Proceeding book. AAEA Meetings, San Antonio, 1996. Erişim adresi: http://digitalcommons.unl.edu/cgi/viewcontent. cgi?article=1006 \&context=ageconfacpub. Erişim tarihi: 07.06.2007.

11. Kohler H (1985): Statistics for Business and Economics. $2^{\text {nd }}$ Ed. Scott, Foresman and Company, U.S.A.

12. Leadtools (2003): SPSS 12.0 for Windows, Version 2.0. Champaign, IL: Lead Technologies, Inc.

13. Microsoft (2007): Office Excel, Version 2007 (10. 2701. 2625). Champaign, IL: Microsoft.

14. Sarıözkan S (2005): Afyon ili yumurta tavukçuluğu işletmelerinde kârlılık ve verimlilik analizleri. Doktora Tezi, Ankara Üniversitesi Sağlik Bilimleri Enstitüsü, Ankara.

15. Turkson PK, Osafo-Adu A (1991): Evaluation of performance in broilers kept on prophylactic medication with coccidiostats. Revue Elev Méd WV Pays trop, 44(4), 491 - 496.

16. Türkiyem-Bir (Türkiye Yem Sanayicileri Birliği) (2009): 1998-2008 ylllarında yem sanayine ait ithalat miktar (ton), değer (\$) ve fiyatlarl (\$/ton). Erişim adresi: http://www.turkiyeyembir.org.tr/yembir/ index.php?area=1\&p=static\&page=istatistikler. Erişim tarihi: 04.11.2009.

17. Yalçın C, Cevger Y, Sarıözkan S, Aral Y, Genç L, İçöz Y (2008): Türkiye'de yaşanan Avian Influenza krizinin kanatl sektörü, köy tavukçuluğu ve tüketiciler üzerindeki sosyo-ekonomik etkileri. TÜBİTAK 1001 Proje Sonuç Raporu, Proje No: $106 \mathrm{O} 457$. 